\title{
TRANSLATION CLASSROOM MANAGEMENT THROUGH PEER ASSESSMENT AND INTERNET BROWSING
}

\author{
I Gst Agung Sri Rwa Jayantini ${ }^{1}$, I Komang Sulatra ${ }^{1}$, Putu Chrisma Dewi ${ }^{2}$ \\ ${ }^{1}$ STIBA Saraswati Denpasar \\ ${ }^{2}$ Universitas Dhyana Pura
}

e-mail: srirwa.jayantini@gmail.com, soelatra01@yahoo.com,chrismaindrawan@gmail.com

\begin{abstract}
This paper tries to describe the modification of peer assessment and internet browsing as a learning model in translation classroom. It includes the procedures applied in the classroom so that the lecturers in translation class can adopt the model and offer a comprehensive learning situation through the use of peer assessment and internet. The modification is a classroom management strategy to be used in delivering translation course for the English department students. The proposed learning model is encouraged by the benefits of peer assessment (Spiller, 2012). and the use of internet in the practice of translating. Here, the modification is expected to create an entirely different atmosphere in translation course. The three key points in this paper are classroom management strategy (Brophy in Korpershoek et al., 2014) peer assessment and internet browsing. Peer assessment is combined with internet browsing as the implementation of classroom management strategy with the purpose of providing the English department students an innovative learning model when they join translation course. By innovative, it means that translation course offered to English Department students is not merely centered on the lecturer's assessment but on peer assessment, which is modified with internet browsing.
\end{abstract}

Keywords: Translation Classroom Management, Peer Assessment, Internet Browsing

\section{INTRODUCTION}

Translation course for English department students usually becomes a prerequisite course that involves a specific learning outcome that is to develop the learners' translation skill. The improvement may be logically gained if the learning atmosphere inspires the learners to learn more so that he/she also can gain more. Besides, the classroom management is one of the influencing factors that has to be the lecturers' concern as they hope to improve the quality of the students' skill and knowledge. In Indonesian higher education institutions, the learning objective in teaching and learning process is usually designed in accordance with the graduate profiles determined by the institution, particularly the faculty and the department. Therefore, managing translation course in an innovative way is strongly required to support the learners with a better academic and enjoyable learning process as well as to broaden their knowledge involving linguistic competence and insights outside of the linguistic world.

Three important aspects discussed in this paper are classroom management strategy, peer assessment and internet browsing. First, it is believed that a well-designed classroom management strategy (CMS) can lead the lecturer and the learners to be involved in a better learning situation to reach the outcomes. Brophy in Korpershoek et al., (2014) confirmed that the management of classroom includes the arrangement of the physical environment, establishing rules and procedures, maintaining students' attention to lessons and engagement in activities. The focus of classroom management proposed in this paper is on the procedures and the activities. Second, the process of assessment must evoke the active participation of the learners which is in line with the contemporary approaches in learning. The approaches focus on the active 
involvement of students in their own learning. With regard to the activity of giving assessment, Spiller (2012:2) stated "Assessment processes in which the teacher holds all the power and makes all the choices limit the potential for learner development in all of these aspects." Third, internet can help to disseminate newborn ideas, theories and findings worldwide to enhance translation theories.

Previous studies show that translation course can be applied in an interesting learning situation involving cooperative work among the students, particularly in university setting. The students can learn cooperatively with their friends through what is called as cooperative learning. Utilizing Gerding Salas' procedures in 2000 that are labeled as 'Cooperative Work Procedure,' Zainudin \& Awal (2012) believed that cooperative learning, or $\mathrm{CL}$, is one of the most commonly utilized forms of dynamic learning. $\mathrm{CL}$ is an active pedagogy. It is believed that $\mathrm{CL}$ demonstrates the most carefully structured end of the collaborative learning continuum. The important finding of the study conducted by Zainudin\&Awal is that in general, a majority of the students preferred group work. However, there was also a significant number of the students under investigation that favored working alone. Thus, this study is designed to combine the preference of working alone while doing translation tasks and the enjoyment of working in group when peer assessment and discussion are conducted to share their experience and knowledge. In classroom management, assessment must be included in teaching and learning process because giving assessment plays a significant role in instructional design. Developing assessment processes that motivate future learning is not an easy task. Careful planning is necessarily done to ensure alignment between the philosophical underpinnings, the intended purpose, and practicalities of the assessment tools and processes (Thomas, Martin, \& Pleasants, 2011).

Peer assessment refers to the assessment given by friends or peer groups which can be realized in different ways like giving feedback, receiving feedback and peer learning. This kind of assessment may be strongly recommended to be used in translation class to replace the lecturer's major role in assessing the students' works concerning the practice that they have done. The peer group exchange of information can help the learners to experience a different situation in translation class. Feedback can also be given in the involvement of friends to give assessment. As the result of evaluation, and systematic continuous school based assessment, feedback can assist in remediating student poor performance. It also helps to achieve cognitive learning objectives (Onuka, 2007). A new atmosphere of learning like sharing with others becomes the different situation that the students can feel during assessing their friends' tasks. In addition, the learners are also able to learn from their peer's strengths and weaknesses so that translation class does not only open the opportunity for personal development but also the chance to grow together through peer assessment. Hence, the learners can make meaning by considering their peers' potentials and errors.

Falchinov in Karolina (2014) gave division on peer assessment. Karolina further investigated reliability and validity of a measure of attitude toward peer assessment that is divided into giving feedback, receiving feedback and peer learning. As it is named, peer feedback focuses more on the activity of giving criticism of other students' performance. It commonly occurs because the students are not confident in rating the peer's performance or works. Meanwhile, in the peer learning, the activities are designed to give the learners more chance to share knowledge among their peers. Specifically, in this study, the expected characteristics of peer assessment applied are rating other students' works and the information each student has can also be utilized to give feedback in the discussion. Peer assessment is believed to be one of the major forms of alternative assessment. The importance of peer assessment has been highlighted in different educational learning and educational research.Some studies that support its importance found that peer assessment can give positive influence on group 
work, social skills and also motivation (Karami \& Rezaei, 2015). Peer assessment reflects a student-centered assessment procedure that is assumed to be useful in encouraging effective learning. Utilizing peer assessment in a public speaking course, White (2009) found that based on survey responses, student perspectives on the use of peer assessment were positive. Peer assessment leads to the promotion of student learning.

The second aspect in the translation classroom management in this study is internet browsing that is modified with peer assessment. In relation to the use of internet in supporting translation work, Budiharjo and Kusumastuti (2013) observed that the contact between internet and translation gives new areas to examine. The use of internet in translation class can be seen from its benefits when the students check their translation accuracy and readability. The information that the students collect is either only the small part or the whole part that is usually published through the facilities of regaining the information provided previously (Purwono, 2008). Internet browsing is the activity that the learners can do in their translation course. The term 'internet' does not mean any translation tools provided through internet browsing that the students can use. The use of internet is to open the students' mind concerning the translation of particular topic that they are not very familiar with.

Finding information through internet browsing is the activity that everyone knows in this global era. Such an activity can be brought into translation class so that the learners are aware of its benefits in helping them finalizing translation tasks (Jayantini et al., 2015). Take, for example if the students are assigned to translate a scientific term in the field of agriculture and biology. The term biosecurity can be translated and popularized as ketahananhayati after the English department students try to consult with the internet. If they are in doubt about their translation or find it difficult to translate particular terms in the assigned texts, they can try to check the appropriate terms by typing the terms and their assumption concerning the appropriate translation version of the terms so that there are several choices appear on the screen of the students' laptops or gadgets.

\section{METHOD}

This research applied the steps of qualitative research that are frequently used in the field of linguistics. As revealed by Djajasudarma (2006), qualitative approach lies in human observation that, in general, has the specific characteristics such as inductive data analysis, human as the research instrument and descriptive presentation of research findings. The steps of this research are based on the principles of the inductive approach (Bochenski in Djajasudarma, 2006) which can be realized through several steps namely ( 1 ) observation of data, ( 2 ) insight into the structure of the data, ( 3 ) formulation of hypothesis and (4) verification of a hypothesis. Method of collecting data in this study is observation that was undertaken through note taking techniques. To collect data from the students concerning their reflection on the application of the teaching model, a survey was also conducted by distributing questionnaires. A number of questions were listed that must be filled by students. Questions are qualitatively designed to investigate the students' comments on the modification of peer assessment and internet browsing.

There are two major steps undertaken in finding the students' reflection on the implementation of peer assessment and assessment. Qualitative research was chosen to deeply dig the students' perception and comments so that the research can result in a recommended model to provide the English department students a better learning atmosphere in improving their translation skill. First, the observation was done in two phases namely (1) after the translation tasks are given to the students and (2) during the discussion when they can use their gadgets and laptops that are connected to the internet. The observation conducted during these two phases was significantly done to give a better understanding on the students' activity during translation process. This step can give an 
overview on the students' ways and attitude when translating the assigned texts.

The observation on how the students assess their friends' work and when they consult with the result they find through internet browsing can give a description on their involvement and how the students understand the benefits of it. In this study, internet is not used to assist the students when they do their translation tasks through machine translation. Internet browsing functions to

\section{RESULTS AND DISCUSSION}

This research is conducted as a preliminary study to investigate how the English department students respond to the implementation of a new way of delivering translation course. It is called as an innovation as the translation class is usually conducted through the lecturers' evaluation and feedback. The research is undertaken to develop a learning model supported with the teaching materials that can be used by the lecturers in enhancing the students' translation skill. The results of observation and interview are presented informally which is supported by the formal presentation through a figure as the visual aid to make the description is clearer. The results of observation are descriptively presented to demonstrate the students' attitude towards the use of peer assessment and internet browsing. In this study, peer assessment is modified with internet browsing to be applied as an innovative model in managing translation course for English department students. The modification gives the learners a wide chance to assess their friends' work and to open a discussion session for sharing and exchanging knowledge and information.

There are four main activities that the students must do in their classroom. Peer assessment and internet browsing make the English department students more active and creative. They do not only translate the assigned texts but also assess their friends' works which mean that they have to act and think actively. They must also be creative to rate their friends' work. develop students' knowledge and enrich their inventory of technical terms from different field of studies. By doing this activity, the students can learn from the definition of a specific term. They can choose the translation of the specific terms. In this way, they are able to give the appropriate translation that makes their translation natural and readable.

The first procedure in this model is giving assignment to translate authentic texts. At this phase, the students are assigned to translate the texts provided by the lecturers. In this study, the texts that the students must translate are taken from professional translators who have finished their translation tasks. This procedure aims at providing authentic texts by that the students are familiar with several texts that need translating. Using machine translation like google translate or any other computer-assisted translation tools is not allowed at this stage to test the students' skill in translating the authentic texts. The students are encouraged to use their skill and broaden their knowledge. In their worksheet, the students should tell the difficulties they are facing during translating the texts in a box found under the texts they have to translate. This is called as annotation to be used as references in the last procedure of the modification like discussion and sharing the process of translating. They even can get valuable information by listing the difficulties that they face.

The example of the authentic texts that the students must translate is listed in the table 1. The table is a proposed course outline used in this study aiming at introducing the learners to the authentic texts that need translating. The implementation will depend on the learning objectives determined in different institutions. Thus, the course outline below may be modified in accordance with the learning objectives determined by the institution through the English department. 
Table $1 \mathrm{~A}$ proposed course outline of translation training Source: Practice Makes Perfect (Jayantini, et al., 2016)

\begin{tabular}{|c|c|c|}
\hline Meeting & Topics & Notes \\
\hline 1 & $\begin{array}{l}\text { Introduction: The } \\
\text { Nature of Translation }\end{array}$ & $\begin{array}{l}\text { Introducing how the class will be } \\
\text { managed, the rules in the class and the }\end{array}$ \\
\hline $2-3,4,5$ & $\begin{array}{l}\text { Translation } \\
\text { Practice (E-I) or (I- }\end{array}$ & $\begin{array}{l}\text { Small Texts : certificate, announcement, } \\
\text { ads, jokes followed by peer assessment }\end{array}$ \\
\hline 6,7 & $\begin{array}{l}\text { Translation } \\
\text { Practice (E-I) or (I- }\end{array}$ & $\begin{array}{l}\text { Literary Texts } 1 \text { : folktales/children stories } \\
\text { followed by peer assessment and internet }\end{array}$ \\
\hline 8 & Mid term Test & \\
\hline 9,10 & $\begin{array}{l}\text { Translation } \\
\text { Practice (E-I) or (I- }\end{array}$ & $\begin{array}{l}\text { Literary Texts } 2 \text { : short stories followed by } \\
\text { peer assessment and internet browsing }\end{array}$ \\
\hline 11,12 & $\begin{array}{l}\text { Translation } \\
\text { Practice (E-I) or (I- }\end{array}$ & $\begin{array}{l}\text { Scientific Texts 1: Economy/medical } \\
\text { biology, etc followed by peer assessment }\end{array}$ \\
\hline 13,14 & $\begin{array}{l}\text { Translation } \\
\text { Practice (E-I) or (I- }\end{array}$ & $\begin{array}{l}\text { Scientific Texts 2: Legal Texts } \\
\text { followed by peer assessment and internet }\end{array}$ \\
\hline 15 & $\begin{array}{l}\text { Translation } \\
\text { Practice (E-I) or (I- }\end{array}$ & $\begin{array}{l}\text { Culturally-bound texts followed by peer } \\
\text { assessment and internet browsing. }\end{array}$ \\
\hline 16 & Final Test & \\
\hline
\end{tabular}

The second procedure in this model is translation practice. It is translation practice as an individual task. This is the time when the students must do their translation tasks individually. It aims at giving each student a chance to experience the process of translating. When practicing to translate individually, the students experience how to translate specific terms, transfer the message found in the linguistic units of source language texts and face the difficulties in translating various kinds of texts. By taking the individual assignment, the students can share their experience and the difficulties when having interaction with the other students during the discussion and peer assessment session. The objective of translation practice can be clearly seen in the following table.

Table 2 Activities and objectives designed to support the implementation of peer assessment and internet browsing

\begin{tabular}{lll} 
Meeting & \multicolumn{1}{c}{ Activities } & \multicolumn{1}{c}{ Objectives } \\
\hline 1 & $\begin{array}{l}\text { Introducing how } \\
\text { the class will be } \\
\text { managed, the } \\
\text { rules in the class } \\
\text { and the teaching } \\
\text { materials }\end{array}$ & $\begin{array}{l}\text { Students understand the syllabus, class } \\
\text { rules, and learning expectations. }\end{array}$ \\
& \\
&
\end{tabular}




\begin{tabular}{|c|c|c|}
\hline $2-3,4,5$ & $\begin{array}{l}\text { Translating small } \\
\text { Texts 1: certificate, } \\
\text { announcement, } \\
\text { ads, jokes followed } \\
\text { by peer } \\
\text { assessment and } \\
\text { internet browsing }\end{array}$ & $\begin{array}{l}\text { Students are able to translate small texts } \\
\text { and understand the errors they make and } \\
\text { be improved by learning from their peer } \\
\text { group's assessment. }\end{array}$ \\
\hline $6,7,9,10$ & $\begin{array}{l}\text { Translating literary } \\
\text { texts: } \\
\text { folktales/children } \\
\text { stories/short } \\
\text { stories followed by } \\
\text { peer assessment } \\
\text { and internet } \\
\text { browsing }\end{array}$ & $\begin{array}{l}\text { Students are able to translate literary texts } \\
\text { and understand the errors they make and } \\
\text { be improved by learning from their peer } \\
\text { group's assessment. }\end{array}$ \\
\hline 8 & Midterm test & \\
\hline $\begin{array}{l}11, \quad 12, \\
13,14\end{array}$ & $\begin{array}{l}\text { Translating literary } \\
\text { scientific texts } \\
\text { followed by peer } \\
\text { assessment and } \\
\text { internet browsing }\end{array}$ & $\begin{array}{l}\text { Students are able to translate scientific } \\
\text { texts and understand the errors they make } \\
\text { and be improved by learning from their } \\
\text { peer group's assessment. }\end{array}$ \\
\hline 15 & $\begin{array}{l}\text { Translating } \\
\text { culturally-bound } \\
\text { texts followed by } \\
\text { peer assessment } \\
\text { and internet } \\
\text { browsing. }\end{array}$ & $\begin{array}{l}\text { Students are able to translate culturally- } \\
\text { bound texts and understand the errors } \\
\text { they make and be improved by learning } \\
\text { from their peer group's assessment. }\end{array}$ \\
\hline 16 & Final Test & \\
\hline
\end{tabular}

The next procedure is peer assessment and internet browsing. After finishing their translation tasks, the students are asked to make a group consisting of four members. They have to exchange their translation works and assess their friends' works based on the rubrics informed and explain to them prior to the process of assessing. It includes accuracy, naturalness and readability. Peer assessment plays a significant role to promote critical thinking and the engagement among the students. The students will have time to discuss with their friends and their time to assess their friends' works. They also can talk to each other about their difficulties. This is the time when the students can learn to rate and sense their friends' errors, weaknesses and strengths. Here, identifying errors refers to assessing how precise the students can find the wrong grammatical construction made by the other students, especially when translating texts from Indonesian into English.

The assessment can be made from the linguistic unit of translation that the other students make. It is ranging from the lowest to the highest level. It means that the students must observe the other students' works from the lexical level to sentential level. Meanwhile, internet browsing is the activity that the students can do while having discussion with their friends. It is part of the discussion process. When the students cannot overcome their difficulties in assessing their friends' translation, they can consult with the information they gain from the internet. It can be applied especially when the students want to check the naturalness, readability and usability of the specific terms found in the texts. The gadgets with internet connection can be used to check those three aspects so 
that the students are convinced to rate their friends' works based on the information and discussion with the other students.

In this study, the specific aspects assessed by the students include three components that are usually used to rate the quality of translation work as modified from Nababan in Anshori (2010) which includes accuracy, naturalness and readability. All of the aspects have the scale of 1-3 which covers the assessment for accuracy, naturalness and readability respectively. Scale 1 shows 'not accurate', 'not acceptable' and 'not readable'. Scale 2 refers to 'less accurate', 'less natural' and 'less readable'. Meanwhile, scale 3 means 'accurate', 'natural' and 'readable'.

The three aspects used to assess the other students' works are explained and discussed prior to the process of peer assessment and internet browsing. Accuracy deals with how accurate the message is transferred. Translation version must deliver the meaning fully. The information must not change and the reader can also read correct grammatical constructions used to transfer the message. The second aspect, naturalness refers to how natural the translation is made. In this case, naturalness is close to the term 'acceptability' since the translation version must be acceptable by the target readers. It must not sound awkward and be familiar for the readers whom translation is specifically done. The last aspect of assessment is readability which is derived from 'readable' in the sense that translation work must be easily understood. It has to be accessible. The idea expressed in the translation must be coherent so that it is easier for the readers to understand the information as if they read the source language texts and get the same benefits with the help of the translator.

The final step in this model is sharing and giving feedback session. the students can share how they assess their friends' works. In this session, the English department students can give the results of their assessment to their friends. The assigned texts are compiled in a book which is used as the worksheet by the students during the semester. The students may give their comments and alternatives for the more appropriate translation version in the worksheet as the results of finding information in the discussion and internet browsing. Having observed the application of peer assessment and internet browsing and conducting a survey involving 80 students of College of Foreign Languages (STIBA) Saraswati Denpasar, 76 students (95\%) enjoy the management of translation course through peer assessment and internet browsing and 4 students (5\%) do not enjoy the model. After investigating more deeply, the seventy six students who enjoy the model, there are three main reasons that make them interested in the modification namely (1) peer assessment motivates the students to be more critical through the observation on their friends' work including the errors, the strengths and weaknesses, (2) peer assessment and internet browsing encourage the students to improve the quality of their translation tasks inspired from the discussion and the information they gain from internet, (3) internet with its search and engine facility can widen the students' horizon and share a lot of information, new knowledge and valuable insights.

The procedures of peer assessment and internet browsing proposed in this study can be shown in the following figure: 


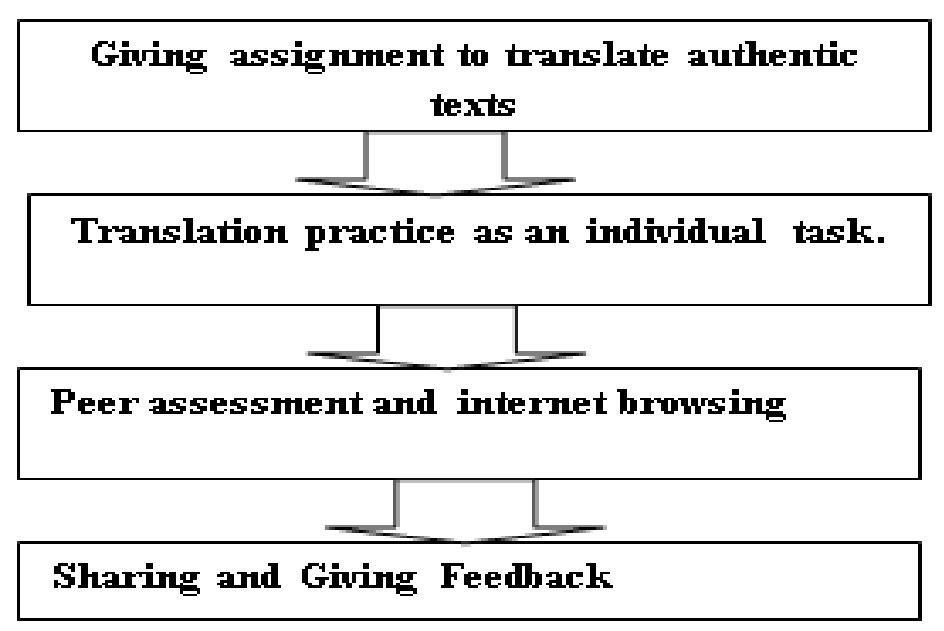

Figure 1

The procedures of managing translation class through peer Assessment and internet Browsing

\section{CONCLUSIONS}

The modification of peer assessment and internet browsing is the central element of translation classroom management described in this study. The strategy includes four main procedures that are assumed to be prospective to create a new atmosphere in learning. It is also hoped that the model can motivate the students to think critically. The four procedures are proposed to demonstrate the process of designing translation classroom management and how the modification is used in translation course. The procedures cover four activities namely (1) giving assignment to translate authentic texts (2) translation practice as an individual task (3) peer assessment and internet browsing (4) sharing and giving feedback. From the survey and interview conducted to check the implementation of the procedures, it is found that most of the students enjoy the use of peer assessment and internet browsing. It shows that peer assessment and internet browsing are eagerly accepted as comprehensive strategies in translation course. Thus, the translation classroom management using peer assessment and internet browsing is recommended to be used as the teaching model in translation course. It is also suggested that further study on its effectiveness in improving the quality of the students' skill is needed for the continuation of the model and validity on its implementation.

\section{REFERENCES}

Anshori, S. (2010). Teknik, metode dan ideologi penerjemahan buku "Economic Concepts of Ibn Taimiyah" ke dalam Bahasa Indonesia dan dampaknya pada kualitas terjemahan [Techniques, methods, and ideology in the translation of 'Economic Concepts of Ibn Taimiyah" into Bahasa Ind. Universitas Sebelas Maret Surakarta.

Budiharjo, B., \& F, K. (2013). Multifunction of Internet in Translation. In 2nd English Language Teaching, Literature and Translation International Conference 2013 Unnes in collaboration with AWEJ \& RELO.

Djajasudarma, T. F. (2006). Metode Linguistik: Ancangan metode penelitian dan kajian. Bandung: Eresco.

Jayantini, S. R., Sulatra, I. K., \& Dewi, C. (2016). Practice Makes Perfect. Denpasar: Cakra Press and STIBA Saraswati Press.

Karami, A., \& Rezaei, A. (2015). An Overview of Peer-Assessment: The Benefits and Importance. Journal for the Study of English Linguistics, 3(1), 93-100. https://doi.org/10.5296/jsel.v3i1.7889

Karolina, V. (2014). A measure of attitude toward peer assessment: reliability and validity. In The 61st TEFLIN International 
Conference 2014.

Korpershoek, H., Harms, T., De Boer, H., Van

Kuijk, M., \& Doolaard, S. (2014). Effective classroom management strategies and classroom management programs for educational practice. Gion (Vol. 501).

Onuka, A. (2007). Teacher-initiated studentpeer assessment. Internatonal Journal of African and African-American Stdies, VI(1), 18-24.

Purwono. (2008). Strategi penelusuran informasi melalui Internet (pp. 1-13). Retrieved from http://eprints.rclis.org/12193/

Spiller, D. (2012). Assessment Matters: SelfAssessment and Peer Assessment. New Zealand.

Thomas, G., Martin, D., \& Pleasants, K. (2011). Using self- and peer-assessment to enhance students ' future-learning in higher education . Journal of University Teaching Learning Practice, 8(1), 5. Retrieved from http://ro.uow.edu.au/jutlp/vol8/iss1/5/?u tm_source=twitterfeed\&amp;utm_mediu $\mathrm{m}=$ twitter

White, E. (2009). Student Perspectives of Peer Assessment for Learning in a Public Speaking Course. Asian EFL Journal Professional Teaching Articles, 33, 1-55.

Zainudin, I. S., \& Awal, N. M. (2012). Translation Techniques: Problems and Solutions. Procedia-Social and Behavioral Sciences, 59(1995), 328-334. https://doi.org/http://dx.doi.org/10.1016/ j.sbspro.2012.09.282 